\title{
The contribution of the Gereformeerder Kerk to Afrikaner culture
}

\author{
I
}

\begin{abstract}
The term culture is employed in this paper in the same comprehensive sense as in Van Til's work.1) Its fullest meaning is contained in the di--ine command to man to replenish the earth and to subdue it. God Almighty, by the strength of his Word, created what we usually refer to as nature in the broadest sense of the word. Man's calling is to "create", in a secondary sense, by unfolding the embryonics of nature. The Lord God created nature, man is bound by divine command to bring forth cul= ture. The two specific and interrelated subjects then are the Gereformeerde Kerk and Afrikaans cul= ture in mutual relation.
\end{abstract}

An analysis of this kind unavoidably meets with the problem stated by prof Karl Holl2) in his ex= cellent book on the significance of the Reformation for the cultural life of Germany and Western Europe. To pinpoint definite cultural institu= tions as creations or direct contributions by a specific church appears to be rarely possible. Max Weber's thesis 3 ) on the relation between pro= testant ethics and the spirit of capitalism is well known and probably as much abused.

Troeltsch 4) sought to uncover a causal link be= tween protestantism and modern civilisation. By and large the attempts of these eminent scholars did not succeed in achieving much more than point= ing to the impact of the Reformation in modifying either by way of diminishing or strenthening existing cultural institutions.

Typical of the nature of an analysis of this order 
is Holl's conclusion on Llither's approach: "Yet the aim is not to supercede the secular order, but rather to enoble it and convert its harshness into something humane."5) This approach does not differ fundamentally from the Calvinistic and reformed view. The main aims in the cultural activities of the reformed faith are centred in the concepts of reformation and sanctification.

A fair amount of energy has been spent in endeav= ours to trace the actual contribution of Holy Scripture, of Calvinism or of the reformed faith to what is popularly called the Afrikaner national or ethnic character.6) The writers in question usually define ethnic character in terms of cul= ture. These writings are open to one general point of criticism in their tendency to link cul= tural traits such as hospitality, religious pract= ices, individualistic patterns etc either to des= cent or to Calvinism, or to a combination of the two. It is doubtful whether this can be accepted as proven. In any case, to anticipate the evidence, the $G K$ rarely if ever superceded existing cultural institutions or initiated new ones. Its influence, spirit and contributions is rather to be found in a particular emphasis, in an observable nuance, in a specific motivation, in a descernable evaluation and in a specific atmosphere.

In order to arrive at a justifiable evaluation of the $G \mathrm{~K}$ in this connection, it should be kept in mind that during phases two and three of its exis= tence, the reformed element represented a minority of the Afrikaner people. For the duration of the second period this element did not include the fashionable elite: they were the border pioneers. The third phase brought no fundamental change in this situation. Affluent and influential citizens were and are rather sparsely distributed amongst the members of the $G \mathrm{~K}$. Tinese are factors of con= siderable importance for the purpose of portraying and understanding the role of the $G K$ in the evolu= tion of Afrikaans culture.

The $G \mathrm{~K}$ has no obvious claim to the title of sole formative factor as far as the history of Afri= kaans is concerned. Afrikaner culture originated 
from merger of Dutch, French and German groups bringing with them their own traditions.

For a limited period the original $\mathrm{G} K$ had one con= dition in its favour. Apart from a minute Lutheran element, the $\mathrm{G} K$ was virtually the only religious factor and directing force. Of course the French Huguenot addition was more than welcome. All cul= ture springs from a religious base. As a spiritual force the reformed faith, ecclesiastically instit= uted in the $G \mathrm{~K}$, imbued the evolving culture with its tenets.

But after a century of unopposed existence the re= formed faith was challenged by new religious and philosophical trends from the European mainland and from the British Isles. In the process its force and range of effect were weakened and con= fined to what may rightly be termed a sub-culture within the Afrikaans culture as such. Especially as far as the "new" G K is concerned, it remains an almost impossible task to distinguish in any specific case its contribution from that of the other Afrikaans churches.

Owing to the Dutch and French Reformed origins of the majority of the South African population of European extraction until deep into the nineteenth century, Afrikaners are popularly described as a Calvinistic people. This continues to be the tenor of liberalistic and permissive English - and Afrikaans - criticism against what is regarded as Calvinistic Afrikaner conservatism. From a differ= ent point of view Calvinism is often regarded as an Afrikaner virtue. What is used as term of abuse by one is cherished as a term of honour by the other. Usually both are wrong.

This thesis stands open to doubt.7) As outlined above the original Calvinistic stream has been polluted and diluted by religious modernism and humanistic philosophy. As a permeating force in the field of culture it was driven back-stage. In the religious sector methodism and pietism even= tually made substantial incursions. Many Afrika= ners may pride themselves on their (alleged) $\mathrm{CaI}=$ vinistic heritage while their overt attitudes and 
actions are in conflict with reformed conceptions of Scriptural pririciple and precept. This direct= ly serves to reveal how essentially foreign this particular life and world view has grown to them. It is a fairly general tendency in South Africa to denote as Calvinist any protestant who has grown up with knowledge of the Bible whatever his sub= jective interpretation of scriptural teaching might be.

To distinguish between three categories of Afrika= ners, seems to be nearer to reality. The first group consists of those practically weened from, and totally unacquainted with, Calvinism and re= formed faith. This includes humanists, liberals, atheists, Roman Catholics, Methodists, followers of Islam and of oriental cults. To a second cate= gory belong those who still accept a Calvinistic tradition but who lack all knowledge of a true re= formed scriptural interpretation and when faced by the demands of recognised Calvinistic principles, are shocked by the challenge and averse to taking it up. Finally we have a minority who still main= tain a deeper loyalty to and an inner conviction of the reformed pastulates even if they are not entirely conversant and acquainted with its basic tenets and practical implications.

The distinction between these categories of Afri= kaners also applies to Afrikaner culture. Humanis= tic, liberalistic, Darwinistic and atheistic trends are observable in Afrikaans cultural practices and conceptions and tend to increase in extent and sub= stance. Probably a major part of Afrikaans culture still contains Calvinistic traits. But even so one has to admit that at least part thereof is hardly more than a crust of tradition, lacking all inten= tion, consciousness and meaning. In Tylor's idion 8 ) Afrikaans culture harbours a good portion of $\mathrm{Cal}=$ vinistic survivals - cultural forms from the past without conscious meaning for the present except as interesting relics.

In so far as the $G K$ is to be considered a contri= buting factor and a staying force in relation to the Calvinistic survivals and sub-culture, several other aspects need attention. The present $G$ K has 
no exclusive demand on what still remains of a re= formed Christian heritage in Afrikaans culture. It shares this honour with both the "original" G K of the seventeenth and early eighteenth century and with the Dopper-element in the Hervormde and the Nederduits Gereformeerde Kerk from the late eighteenth century to the present. In addition to tracing the origin of those Calvinistic forms, contents, influences and trends which are present, to a single spiritual mother, the $G K$, recognition should be given to different ways of their coming into existence.

They either stem from direct initiative and action of the church as an instituted body or - probably in the majority of cases - from the behaviour and actions of members of the church, motivated and directed by, and acting on, the strength of their religious convictions. Hence I choose to refer to the role of the gereformeerdes so as to include both the ecclesiastical institution and its members in their individual office of the faithful which accompanies them in the total spectrum of their secular life.

Finally the honour for the various contributions can neither be shared by all members nor by all of them equally. In the process of evolving a culture it is a recognised fact that followers and main= tainers are more numerous than creative spirits and that active reformers are outnumbered by passive traditionalists. In attempting to evaluate an in= stitution's impact on a specific cause, it remains a sine qua non of methodology not to allow an equal rating to each and every member. The $G K$ and the gereformeerdes are no exceptions to the rule.

When not shocked outright, outsiders are at least very often puzzled by what appears to them as a kind of dualism and contradiction in the behaviour of the gereformeerdes. They seem to embrace con= flicting approaches in their system of values, and to make curious bedfellows of static conservatism and amazing progressiveness; they appear to be 
verkrump and verlig simultaneously. Of itself this is not as strange a phenomenon as people are apt to believe. Every society provides sufficient examples of people extremely liberalistic and modernistic as far as religious concepts and prac= tices are concerned, but exceedingly conservative in secular life or vice versa.

The popular image of Afrikaners and particularly of the gereformeerde element is one of die-hard traditionalists both in religion and in national and cultural affairs. They are thought to stick to the ways of their fathers most conscientiously. Hence any progressive action on their side usually is found astonishing. It has been said jokingly that the gereformeerdes take one step forward, then halt and look back with the question: Where is Dort? of course many a true word is spoken in jest.

In a specific sense conservatism correctly describ= es the culture of the Afrikaners and their psychomental complex.9) For a better understanding of the apparent contradictions it is necessary to distinguish between basic principles and their application to life situations. A tendency towards general cultural traditionalism cannot be denied, but more often the gereformeerdes remain loyal to their basic religious and scriptural principles. Due to explicable circumstances a trend to an overal conservatism embracing all spheres of life also affects the religious premises to the extent of fundamentalism and biblicism. The preceding outline of South African ecclesiastical and cultu= ral history ought to provide some explanation of the conservatist attitude.

Both the Dutch settlers with their Dordt background and the Huguenot immigrants who had to flee their land of birth for the cause of their reformed faith, seriously upheld the basic religious princi= ples of the Reformation according to the Calvinist approach. Towards the second half of the eight= eenth century this was referred to as orthodoxy in contrast to the "modernistic" and "libertine" religlous creeds of the time. Circumstances in the new country were favourable to a hardening of 
this orthodoxy. On both the religious and secular front Christianity met and clashed with heathen beliefs and life. This was the basic difference between homo Europeana and homo Africana and be= came the yardstick of separate identity.

At the end of the eighteenth century this develop= ment was stressed from a new angle. New political and ethnic relations were involved. A contact was forced - right from the outset in the form of con= flict - between the Afrikaner people with its re= ligious and secular 1 ife rooted in and fed by the orthodox or Calvinistic reformed faith, and the largely modernistic protestant British. Two ways of life with two different cultural systems collided. For a second time at least part of the Afrikaners sought security and safety for their national identity in a reformed religious orthodox creed in order to keep themselves distinct from the foreign European element in its usurpation of political authority.

Naturally sociological forces played an important role in the ensuing process. The orthodoc part of the population occupied the more isolated rural areas. As farmers and rural residents they were generally less exposed to influences from abroad and less open to change than their urbanised compatriots. At the same time the inland pastoral= ists lived face to face with indigenous barbarism and heathenism and experienced the logic of these differences at first hand. The whole problem of, and contrasts in, attitudes to border politics are closely interwoven with these religious and secular incompatibilities.

With the Bible and a few orthodox authors as their sole literature in a situation of pastoral semiisolation and strife with foreign and heathen peoples, the trend towards a culture strongly resembling the patriarchal pattern and attitude of the old Testament, cannot be regarded as amaing. Observed in retrospect, these were God's measures to safeguard the reformed faith against contamina= tion by digressive influences via Dutch and British sources. The idea of a chosen people in the midst of the children of Ham, the consciousness of a 
divine calling to tame the wilderness and to main= tain their identity as a Christian people, were clear indications of the general old Testament im= print on the life, thought and culture of the emerging Afrikaner ethos. They lived a life of sobriety and aristocratic simplicity. Inhibition of emotions in interpersonal relations, especially on the side of the male, was a strong cultural trait.

In general these farmers developed an independent spirit. They possessed a set of norms firmly based on scriptural principles. These were accept= ed as the ultimate truth and stood in clear dis= tinction from the modernistic, libertine and human= istic systems of values with a subjective and re= lativistic character. Different religious creeds lead to differing directions for creative action. Liberty was a highly appreciated value; indivi= dualism was cultivated by the social situation but also imbued with a singular quality derived from the faith in the Lord, their refuge. Both liberty and individualism were curbed by obedience to the Word of God. Liberty had to provide the opportu= nity to serve the Lord according to his Word; individualism to execute one's calling in the service of the Almighty and as members of his fold. Neither ever was transformed to an indivi= dualistic liberalism.

The apparently dichotomous attitude and behaviour referred to previously tends to be misleading. It is due neither to lack of consistency nor to un= certainty of principle. Superficially dialectical, it does not fit into Hegel's system. It is truly and essentially Biblical dialectics: die to gain everlasting life; the Christian has to be freed from the slavery of Satan and sin in order to be made a slave of Christ; bound by the word of God in order to attain liberty. Nothing can be more erroneous than to typify this manner of life as a middle of the road attitude in an effort to avoid the sharp edges or the pitfalls to the right and to the left. Essentially it is the outcome of a different approach, different from others in pre= mise as well as in aim. Hense it cuts through most of the popular contrasting distinctions: 
conservative vs progressive, national vs cosmopoli= tan, orthodox vs liberal. Consequently it leads to different controversies and contrasts with what is usually regarded as being harmonious.

The preceding paragraphs are meant to supply the necessary background for an evaluation and appre= ciation of the gereformeerde contribution to Afrika= ner culture.

Intensely national and possessing a strong ethnic consciousness, the gereformeerdes took a strong and clear stand on the relation between church and people (volk) The ideas of "volkskerk" and "staatskerk"10) are unequivocally rejected. Church membership does not derive from ethnic membership or political citizenship. Nevertheless, a parti= cular church is rooted in a particular people and primarily functions within that people. It exists within a nation in that the christian members of the specific nation belongs to the church of Christ. More-over, a people continues its exis= tence into the new dispensation solely in its redeemed members as members of the people of God and as heirs to life eternal through Jesus Christ. The church thus exists temporarily within a people and at the same time transcending all boundaries and limits of this life in its capacity and nature as Church of Christ and as people of God.

According to the reformed concept of the nature of the church it cannot be subject or handmaiden to either nation or state. Its prophetic office has to be practised amidst the people in the divine proclamation: Thus saith the Lord ... In the midst of the people the church has to live up to the demands of its royal office by governing those within its sphere of spiritual authority in order to obey the divine commands and to walk in the paths of righteousness for his name's sake. It must be priest to the people in its prayers for reconciliation of their sins, for blessings, for peace and order and for sound government. To serve in the kingdom of Christ is a people's ulti= mate destination. To believe this and to practice it means to be truly Christian-national. 
The bearing of this approach upon the whole gamut of secular life - not secularistic - especially on politics, can hardly be overrated. Gereformeerdes are noted for their patriotism and nationalism. Rarely is a minister of the G $K$ or of gereformeerde conviction to be found in the ranks of an English oriented political party. Nevertheless, this does not prevent gereformeerdes from differing from the party to which they belong. During the turbulent days of the second world war, a considerable num= ber of prominent gereformeerdes occupied leading positions in the ossewa-Brandwag. This is one outstanding example of the apparent dichotomy in gereformeerde behaviour. Attempts to stain their reputation by describing them as Nazis were total= ly off the mark. They were strongly republicanminded and -motivated and were pro-German only in so far as the hope existed that by beating the British, the coveted republic of South Africa would materialise. This action serves as an indi= cation of their political independence too.

In the hearts of a substantial component of the gereformeerde Afrikaners a conviction of the neces= sity for Christian national politics still endures. The astonishing situation presents itself that they do not secede from the existing party to form a separate and independent faction. This attitude, too, can be explained only by the principle of the reformed approaches of national loyalty, coupled to the command to reform. As long as the possibi= lity and opportunity to set right what is wrong presents itself, they are not to break away. A kind of independent and distinctive attitude with= in the party or group to which they are affiliated seem to be characteristic of the gereformeerdes. This is perhaps best illustrated by the tenor of the newspapers and journals initiated and control= led by gereformeerdes. Within the political party they support, they tend to form a critical and in= dependent-minded element, supporting where agree= ment exists, criticising where differences arise.

Prof $L J$ du Plessis once made the statement ${ }^{11}$ ) that Calvinism very seldom attains the position of a ruling or governing force. Its essential role is that of a controlling power. In biblical idiom 
it could be formulated as the relation of prophet and king, with the reformed faith in a apostate world in the position of the prophet and the king's conscience. This more or less portrays the role of the gereformeerdes in South African poli= tics. The more imminent the danger, the more strongly the gereformeerde element comes to the fore and the more its voice is heard.

The specific principles and form of ecclesiastical government of the $\mathrm{G} K$, a kind of controlled democ= racy, was not, of course, without effect on gere= formeerde politics. Paul Kruger was an eminent ex= ponent of a political philosophy and practice professing the necessity of the voice of the people without accepting the dictum of vox populi, vox dei. The highest loyalty and obedience was due to God, not to the people. Reformed politics can= not be pragmatic, they must be principled. The high rating of the lawful political authority was clearly expounded in Kruger's rejection of the judiciary's demand to test the decisions of the legislature.12) High appreciation of the office without deifying the person in the office, is characteristic of gereformeerde political philosophy. officebearers should be democratically elected but obedience to them derives from the authorıty of their office.

A similar characteristic feature of gereformeerde politics is the role of morals. Political effic= iency and brilliance does not override moral laxity. This even applies to the political lea= der's religious doctrines. The more orthodox gereformeerdes in the Transvaal Republic, in fear of God's afflictions resulting from the presidency of the liberal Rev Burgers, chose to leave the count= $r y$ in what is known as the Dorslandtrek (the desert- or thirstland trek).13)

A clear distinction between state and church, be= tween secular and ecclesiastical authority, be= tween the rule of the state and the ministry of the church, is a tenet of gereformeerde political approach. The distinction, however, does not imply isolation neither does it mean subordination. This concept finds its prototype in the old 
Testament relation between king and prophet. The respective fields of activity of the two institu= tions partly coincide but their functions differ according to the basis of their distinctive origins. The state or king, wields authority, derived from the king of kings, over believers and non-believers in its area of jurisdiction. His sign of office is the sword. The sphere of minis= try of the church or prophet cuts across the boundaries of state although it is limited to the faithful only. Its sign of office is the word of God - the Bible.

The instituted church as such has to refrain from indulging in politics. Its political actions are limited to awakening of the conscience, to admoni= tion and reprimand. Its members are bound to par= ticipate in politics in their capacity as christ= ian citizens. They expected to practice in poli= tics what they are taught by the church. The church stands under an obligation to the govern= ment to pray for the rulers, for peace and order, for good government, as well as to admonish by way of dialogue and communication and not in the first place by way of demonstration, and to teach its members to be obedient and responsible citizens.

Undoubtedly the most distinctive and important contribution of the $G \mathrm{~K}$ to Afrikaner culture is manifested in the field of education. Even under the most dire circumstances of border pastoralism or on trek, a high premium was maintained on the acquisition of a basic knowledge of the "three R's" for the sake of religious education. Young= sters had to be prepared for shurch membership through confirmation. By stress of circumstances the curriculum was more than once limited to Biblical history, the Heidelberg catechism and the psalmody. In this bare minimum, the religious core and foundation $O F$ education, serving as grounding for morals en ethics, was fortunately maintained.

This served well for the renaissar ce of education when better times dawned. The church was to con= stitute the foundations of what came to be called C N O or Christelik-nasionale onderwys (Christian 
national education). The term is self-explanatory. The primary stress on Christian education sprang from the conviction of the overwhelming importance of a pious life in the service of and according to the precepts of the word of God, and found its logical and organic link with the almost exclusive= ly religious education of the past. At the same time it held the promise of a safeguard for the maintenance of the Christian identity in contrast with the coloured heathen tribes. This helps to explain the "national" part of the term. Educa= tion was valued as an instrument or an agent en= abling the national group or the people to fulfil its cultural calling and to fit it for the strug= gle for existence. A national education, spring= ing from the heart of a people, rooted in its tradition, culture and values and destined to serve and develop its mental, spiritual and mater= ial needs, was regarded a sine qua non.

The core of the curriculum included three branches of learning: scripture, the mother tongue and the national history. Scriptural knowledge was not valued solely as a common school subject. To qualify as Christian education, the school in all its activities and the whole of its atmosphere has to be saturated with a Christian spirit ind guided by scriptural principle. On the organisational level three partners act in co-operation: the group of religiously like-minded parents, a teach= ing staff of qualified and pious teachers and the state.

This ideal has never been fully attained. Handi= capped by circumstances it lead either to denomina= tional schools (church schools) or to government schools. Denominational schools were usually short-lived because of the financial burden on their supporters. Government schools never suc= ceeded in satisfying the gereformeerdes and the $G \mathrm{~K}$ because of a lack of a thoroughly Christian spirit in the schools and a lack of Christian content in the subjects taught. $\quad \mathrm{C}$ O-supporters continual= ly stressed and still emphasize a system of "parent schools", meaning a differentiated school= ing system organised on the basis of schools for groups of parents of common faith. 
The introduction of legalised separate language schools brought partial satisfaction but even the latest Education Act ${ }^{14}$ ) does not wholly reassure gereformeerdes. The role of the parents in the con= trol of schools, for example is not given enough prominence. They also harbour a feeling of dis= quiet because of the possibility that, with a change of administration under circumstances of increasing secularisation, a government school has no safeguard against an unchristian spirit and practice, notwithstanding the legal guise of Christian education.

The logical extension of the $\mathrm{G} \mathrm{K}^{\prime} \mathrm{s}$ stand on $\mathrm{C} \mathrm{N} O$ is its insistence on a Christian science. What is demanded for primary and secondary education must logically be claimed for post-secondary in= struction also. Christian education at all levels needs Christianly educated teachers, trained either by professional colleges or by universities. Professional training and instruction in the use of subject material have to harmonise in their approach both to the child and the teaching mater= ial. That approach must be a christian one. And what applies to teaching undoubtedly applies to every other profession too.

The $G K$ specifically experienced the need from two sides. In order to put its ideal for Christian education into practice in the private $\mathrm{C} N \mathrm{~N}$ schools, or at least to maintain an element of Christian teaching in government schools, teachers pious by upbringing as well as christian in train= ing were regarded a sine qua non. Great sacrifices were made for the establishment of a christian teacher=' traininy college.

Even 'iore pressure was felt in the field of the ministry. The newly re-established church had to find properly trained pastors. The output from the Netherlands was inadequate. In addition, with its strony leaning towards the national community, the $G \mathrm{~K}$ preferred a ministry recruited from its own spiritual and national ranks. This soon necessitated an additional institution, originally called the Literary Department of the Gereformeerde $T S$, which taught the secular subjects as 
auxiliaries to the theological encyclopaedia. This in due course developed into the Potchefstroom Uni= versity for Christian Higher Education. Right from the outset the founders proclaimed their aim of an institution for practicing and teaching the broad spectrum of science "in Thy light". (Psalm 36:10.)

This naturally made another valuable contribution to the academic sphere of culture. A Christian training college and a Christian university offered the laboratory and the cathedra for evolving a Christian or scriptural science. To enumerate the most outstanding achievements resulting from this source is difficult. But one thinks spontaneously of prof $J$ Chris coetzee in the field of education, prof H G Stoker in the sphere of philosophy and prof $L \mathrm{~J}$ du Plessis in the area of political. sciences. These men and others alongside or fol= lowing in their tracks are firmly embedded. $n$ the reformed sub-culture and are gaining ground in the reformed circles of the related churches. As far as theology is concerned - and this applies to educational theory and to philosophy - the gerefor meerde academics maintained a strong attachment to their reformed colleagues in the Netheriands. In a small way this perhaps also served to keep the bonds with the Dutch cultural heritage alive. Kuyper and Bavinck and scholars of their calibre and school of thought undoubtedly exerted consider= able influence on Afrikaner thought, mainly by way of their impact on Afrikaner leaders in the theo= logical educational and philosophical world.

To isolate a definite gereformeerde influence in the field of arts is a far more complex and difficult commission. It is doubtful whether the gereformeerde component made any strong impact on this sector of culture. The eminent theologican and poet, Totius, stands out as a notable, but at the same time solitary, exponent. Both his secular and his relig= ious poetry, the latter consisting of the Afrikaans psalmody and the rhymed version of a number of old and New Testament texts, represents an exceptional trend in Afrikaans literature. Jan Lion Cachet tried his hand at prose. His writings belong to the childhood of Afrikaans literature and do not reveal a strong and distinctive tenor. This applies 
to the satire and humor of dr O'Kulis too.

Prof G Dekker succeeded in gaining for himself an independent platform with a relatively strong and characteristically christian spirit in his liter= ary criticisms and evaluation of art in general. Both the quality of his work and his outstanding personality contributed to the acceptance of his stand in wider circles than that of the gereformeer= de world. The reformed component was, however, unable to exert an influence and to make a wider impact on the arts than that enumerated above. On the academic level intense interest is being ap= plied to a Christian philosophy of art.

A considerable part of Afrikaner tradition is con= cerned with inter-ethnic and inter-race attitudes and practices. Afrikaner history in particular is for the greater part moulded by contact with aboriginal and "imported" tribes, peoples and in= dividuals of vastly different colour, race, cul= ture, civilization and religion. In addition the other historic tread of contact with British con= querors and immigrants runs through nearly two centuries of Afrikaner history. Almost without exception, contact throughout spelled conflict. The outcome was a peculiar psycho-mental complex of attitudes and behavioural institutions usually expressed as a system of "apartheid" or separate= ness.

The $G K$ as well as its adherents and the wider group of gereformeerdes took a consistent and clear stand in favour of "apartheid" in close co-opera= tion with the rest of Afrikanerdom. In due course the concept in these circles acquired an independ= ent and peculiar meaning. As indicated earlier, apartheid germinated from the original and general Black-White distinctions but not in its overt sense of difference of colour. The origin was far more than skin deep. The fundamental difference was embedded in the contrast of Christian vs heathen and civilized vs barbarian. The somatic differences especially that of colour however, served a practical purpose in acting as a naive and overt indication of a complex of cultural and civilisational characteristics. But it outstayed 
its usefulness. Practically the difference of identity and the deep desire to maintain and to safeguard their Christian and civilized identity was expressed by the numerical minority of Euro= pean immigrant-settlers, in the idiom of colour.

The struggle for existence as a separate ethnic entity, emphasized these somatic differences. The old Testament life pattern imbued it with further meaning. In this process of generalisation and modification of the true meaning of racial differ= ences, the gereformeerdes took the same direction as the greater population. Early in the second half of the twentieth century the $G \mathrm{~K}$ experienced a measure of uneasiness in pursuing this course. The synod of 1955 appointed a commission to study and to advise the synod to beheld the following year on the question of race in the light of Holy Scripture. Remarkably the mandate did not include a study of "apartheid" and in addition the politi= cal and social problems were submitted to the authority of the Word of God.

Six years later the commission's final report was submitted. Synod accepted as leading suziptural dictums the principles of charity and righteous= ness in all questions of ethnic and race relations. It shifted the focus from race to people on the strength of the argument that the Bible does not even mention race but clearly speaks in terms of peoples. It denied the idea of superior and in= ferior peoples or races. It further formulated the implications of these fundamentals for situa= tions of common worship, marriage, ecclesiastical organisation, etc.

On the question of common worship the synod took the stand that since divine service is an open act of worship, no scriptural objections can be for= warded against participation of people of all race and culture. The normal situation, considering differences in language, culture etc, would how= ever, be the provision of separate congregations and opportunities for worship for the different ethno-racial groups. The same applies to racially mixed marriages. The attitude of the $G \mathrm{~K}$ and its approach to the field of inter-ethnic and inter- 
racial relations is best expressed in the struc= ture adopted in its ecclesiastical organisation after the institution of new congregations as a fruit of its missionary work amongst Bantu peoples and Coloureds.

They all belong to a single Gereformeerde Kerk in Suid-Afrika with one general synod made up of equal numbers of representatives from the various nation= al synods of the Bantu peoples, coloureds and Whites. In considering the extreme importance of the service of the Word, separate local churches are instituted for the different peoples, each with its broader connections and meetings of cir= cles, in particular territorial and national synods. By meeting in a general synod the idea of ecumenical unity finds expression. Channels for mutual contact are provided on all levels.

Both the decisions of the 1961-synod and the organ= isational structure of the $G \mathrm{~K}$ reveal the latest stage of the evolution of the gereformeerde tradi= tion pertaining to ethnic and race relations. Group differences on the basis of ethnic identity. culture, language etc. are recognised and strongly emphasized without, however, accepting isolation as a substitute. Contact is maintained both horizontally and vertically, from the core of the local congregation to the broader unity of the ecumenic synod, and without excluding in principle or practice personal contact over the boundaries of either congregation or synod. These develop= ments represent a most important contribution to present-day Afrikaner culture and are accepted in wider circles than that of the $G \mathrm{~K}$ only. It is exerting its impact in spheres outside the eccle= siastical world and serves as a model for political structuring too.15)

The reformed faith awarded a high premium to work and to economic independence. The $G \mathrm{~K}$ has a repu= tation for devoted diaconal work and priestly charity. The church jealously guards this as its specific service. It is opposed to dependency on state welfare and to secular social work. The idea of institutional care for the aged and for neglected children had a hard and uphill struggle 
before being accepted in the $G K$. The majority of the members of the $G K$ could be classified as mid= dle and lower middle class. During the era of poor whitism and both rural and urban poverty, the church had to face a substantial rate of poverty. Nonetheless, its rate of pauperism was exceedingly low. 16)

The gereformeerde population was given to a soher and simple life. Extravagance runs counter to re= formed convictions. The gereformeerde ethos rejects excesses though the image of a gereformeerde as a melancholy and gloomy person is a caricature. In their entertainment the basic pattern of sobriety and avoidance of excesses and extravagance is observable. The gereformeerde rejects dancing, gambling and excessive drinking as sinful.

In the economic sphere the contributions of the gereformeerdes are slight. The G $\mathrm{K}$, perhaps more than its related denominations, is a church of farmers, exclusively pastoralists rather than agriculturists. In practice it came nearer to Luther's economic concepts than to Calvin's. Occupations and economic pursuits apart srom farming were introduced into the ranks of the gereformeerdes mainly by the Dutch immigrants to the Transvaal Republic in the days of Paul Kruger. They manned the civil service, entered trade and commerce and the professions, mainly teaching.

South Africa's industrial revolution, following on the economic depression and the era of the poor white problem, enticed and forced the Afrikaner ruralists to the towns and cities. These pioneers of Afrikaner townsmen started their urban life as labourers in the mines and on the railways and to a lesser extent in the embryonic industries. In ever growing numbers they entered the civil ser= vice from the lowest ranks, the police force and the teaching profession and still later law and medicine. Finally they made their debut in the fields of commerce, trade and industry. For the gereformeerde Afrikaner, Potchefstroom University opened a door to the academic profession.

It remains an open question whether the relatively 
few gereformeerles in the later economic sectors have left any imprint on these pursuits or have succeed= ed in creating a distinctive cultural pattern. Law, engineering and medicine for instance were previously taught almost exclusively at English orientated and so called neutral universities. The next stage was the establishment of law faculties, engineering departments and schools of medicine on Afrikaans campuses. At the present time the only Christian university in South Africa still lacks the facilities for teaching engineering and medicine.

I I I

To conclude: It is extremely hard, if not impos= sible, to pinpoint the gereformeerde influence on Afrikaner culture. The researcher would be wise to be on the look-out for intentions and goals, interpretations and motivations different from those customary, to discover a leaning towards principle rather than to pragmatics, to catch sight of a trend away from humanistic approaches and in the direction of a straight and to the point appeal to Scripture and to scriptural direc= tives. The fruits of gereformeerde principle and practice cannot easily, if ever, be sorted out, counted and weighed. None the less, they truly exist and are undoubtedly real.

It is largely of a spiritual nature. Gereformeerdes wear the same clothes, drive the same cars, serve on the same committees, attend the same schools, belong to the same political parties and sports clubs, read the same papers as their fellow nationals - but with a difference.

To grow acquainted with the varied kaleidoscope of Afrikaner life and customs, means to experience the atmosphere of a kind of submerged gereformeerde life style - submerged in the general bustle of national activity and at once clear and discern= able when coming face to face with its manifesta= tions. It is observable in the national ethos and in everyday activity. 
Teachers brought up in gereformeerde homes possess a quality undefinable and different from their colleagues in the same profession and something in addition to professional ability. They express themselves differently in their appeal to and in formulating principles, both in general and in those specifically relevant to their profession. The same applies to men and women in other profes= sions. Exceptions do of course exist. One en= counters those who have lost this gereformeerde cachet. On the other hand one meets men and women, members of the other Afrikaans churches, emanating from the same atmosphere. Yet, the gereformeerde minister can easily be distinguished from his col= leagues in the "sister churches" by his style of preaching, his pulpit terminology and his

homilitic expressions, the pattern and tone of his prayer. The main tenor in gereformeerde devotions is the humble approach to the sovereign and holy God Almighty, the avoidance of all familiarity as well as the use of pet names. This attitude per= vades the gereformeerde life in its characteristic feature of shunning all forms and semblance of sentimentalism. It tends to give the impression of a cold and rationalistic religion. It is also, falsely, believed to result in an undue accent on dogmatic learning and to the neglect of personal relations with our Father in heaven.

It is no exaggeration to contend that these rather vaguely indicated qualities and characteristics are rarely totally assimilated by "proselytes" from the sister denominations. There is the general saying that a person has to acquire it with his mother's milk.

Finally then, one has to admit, with deep grati= tude and at the same time with the utmost humility, that the Gereformeerde Kerk, by God's eternal grace, was priviliged to contribute a spiritual feature to the cultural life of the Africaner, one difficult to isolate, to define and to measure, but none the less real and recognisable to the keen observer. It is a contribution springing from the reformed faith in Calvinistic tradition and perpetuating features of that peculiar spirit= ual aristocracy and yet humble faith, based on the 
Consciousness of man lost in sin, redeemed by grace and springing from the acceptance of the absolute authority of the word of God.

J H Coetzee

$\mathrm{PU}$ for $\mathrm{CHE}$ 
BIBLIOGRAPHICAL REFERENCES

1. Van T1l, H R, The Calvinistic concept of culture. Phila= delphia, 1959.

2. Holl, Karl, The cultural significance of the reformation. N Y, 1959 .

3. Weber, Max, Wirtschaft und Gesellschaft. Ttibingen, 1922.

4. Troeltsch, Ernst, Die Soziallehre der christlichen Kirchen und Gruppen. Tubingen, 1923.

5. Holl, Karl, p 28.

6. Several works can be quoted. The most representative examp= les $i$ a would be: Bosman, $F$ C L, Die franse stamverwant= skap en kulturele bydrae tot die Afrikaanse volk In Van den Heever, C M en Pienaar, $P$ de $V$, Kultuurgeskiedenis van die Afrikaner, Kaapstad, 1945. Also Coetzee, Abel, Die wortels en kenmerke van die tradisionele Afrikaanse lewenstyl In Koers, XXXVII/3 en 4, Des - Feb 1970.

7. The following articles treat with this issue in greater par ticulars: Coetzee, $J H$, Must an Afrikaner be a Calvinist In New Nation, June 1969, and by the same author, Die Afrikaanse volkskultuur In Die Taalgenoot, Okt 1964 .

8. Tylor, Edward B, Primitive culture. London, 1920.

9. For an exposition of the concept see Shirokogoroff, S M, The psychomental complex of the Tungus. London, 1935.

10. A otaatokerk means a church recognised by the state as official denomination. A volkskerk 1ndicates the idea that members of a specific people or nation are ipso facto mem= bers of a "national" church.

11. Du Plessis, I $J$, Die Calvinisme in sy aktualiteit gehand= haaf In Op die voorpunt van die tye. Stellenbosch, 1945.

12. Kruger, S J P, The memoirs of Paul Kruger. London, 1902. Morley, op cit, arrives at more or less the same conclusion.

13. Van der Walt, A J, Noordwaarts. Potchefstroom, 1906. Also Kruger, S J P, op cit.

14. Act $39 / 1967$.

15. V1de the Synodal acts of the Geref Kerk 1958, 1961, 1967, 1970 and 1973. Also Coetzee, J H, Die Gereformeerde Kerk en die rasseverhoudings In Du Toit, $S$ (red): Die Gerefor= meerde Kerk 1859-1959.

16. Coetzee, $\mathrm{J}$, Die barmhartigheidsdiens van die Gereformeer= de kerk in Suld-Afrika, 1859-1949. Potchefstroom, 1953. 